\title{
Infeksi Bakteri Gram Negatif di ICU Anak: epidemiologi, manajemen antibiotik dan pencegahan
}

\author{
Amar W.Adisasmito, Sri Rezeki S. Hadinegoro
}

\begin{abstract}
Rumah sakit dan unit perawatan intensif (ICU) merupakan breeding ground atau tempat berkembangnya bakteri yang resisten/multiresisten antibiotik, disebabkan penggunaan alat invasif, kontak yang sering antara staf rumah sakit dengan pasien sehingga memudahkan terjadi transmisi infeksi, intensitas penggunaan antibiotik yang tinggi serta penggunaan antibiotik empiris yang berlebihan. Hal tersebut terjadi karena pasien yang dirawat di ICU pada umumnya menderita penyakit berat dan dalam kondisi imunokompromais. ${ }^{1,2}$

Bakteri Gram negatif mempunyai tingkat resistensi tinggi karena mempunyai mekanisme resistensi yang multipel. Mekanisme resistensi bakteri Gram negatif terhadap antibiotik b laktam, terutama disebabkan karena bakteri Gram negatif menghasilkan enzim b laktamase. Berdasarkan hal tersebut, dapat dipastikan bahwa infeksi oleh bakteri Gram negatif merupakan ancaman, terutama pada pasien imunokompromais. ${ }^{3,4}$
\end{abstract}

Kata kunci: bakteri Gram negatif, infeksi nosokomial, antibiotik, ICU.

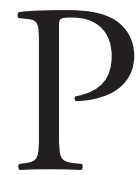

enyakit berat seperti bakteremia, sepsis, pankreatitis, trauma multipel, luka bakar, keganasan, operasi besar dan lainnya berisiko untuk terjadi systemic inflammation response syndrome (SIRS). ${ }^{5}$ Pada SIRS dilepaskan berbagai sitokin yang berlebihan (cytokine redundancy), yang tidak menguntungkan respons imunologis pejamu terhadap infeksi sehingga memperberat penyakit. Kondisi imunokompromais antara lain leukopenia/ neutropenia, defisiensi komplemen dan penyebab lain seperti terapi kortikosteroid, penurunan jumlah dan/ atau fungsi makrofag pada imunitas non-spesifik,

\footnotetext{
Alamat Korespondensi:

Prof. DR. Dr. Sri Rezeki S Hadinegoro, Sp.A(K).

Divisi Infeksi dan Penyakit Tropis. Departemen Ilmu Kesehatan Anak FKUI-RSCM, Jakarta.

Jl. Salemba no. 6, Jakarta 10430.

Telepon/Fax.: 021-391 4126.

Dr. Amar W. Adisasmito, SpA

Kelompok Kerja Infeksi RSAB Harapan Kita Jakarta.

Telepon: 021-5668284 Ext 2281 Fax. 021-5601816
}

ataupun penurunan jumlah dan/atau fungsi sel limfosit T pada imunitas spesifik. ${ }^{6}$

Munculnya resistensi terhadap berbagai antibiotik dipengaruhi oleh pemakaian antibiotik itu sendiri. Semakin lama seorang pasien mendapat terapi antibiotik, akan memudahkan timbulnya kolonisasi dengan mikroba yang resisten antibiotik. ${ }^{7,8}$ Bila antibiotik diberikan berlebihan, tidak adekuat, monoton (satu jenis terus menerus) maka akan mengurangi efektifitasnya sehingga menimbulkan resistensi terutama bakteri Gram negatif. ${ }^{1,9}$

Bakteri Gram negatif yang paling sering diisolasi di ICU anak adalah Pseudomonas aeruginosa, Escherichia coli, Enterobacter cloacae, dan Klebsiella pneumoniae. Sumber bakteremia tersering adalah infeksi saluran kemih dan pneumonia. ${ }^{10,11}$ Enterobacteriaceae penghasil enzim extended spectrum blactamases (ESBL) resisten terhadap cefotaxime pertama kali ditemukan adalah Klebsiela dan Seratia di Jerman pada tahun 1983. Dalam beberapa tahun, ESBL pada E.coli, Acinetobacter sp, dan Klebsiella sp sudah tersebar di seluruh Eropa. ${ }^{12}$ 
Dilema yang dihadapi adalah di satu sisi diharapkan mengurangi penggunaan antibiotik untuk menurunkan resistensi bakteri, tetapi di sisi lain terapi antibiotik yang terlambat atau tidak adekuat secara signifikan akan meningkatkan angka kesakitan dan kematian, terutama pada bakteremia oleh bakteri Gram negatif. Strategi antibiotik terbaik tampaknya adalah membatasi secara ketat penggunaan antibiotik yang tidak perlu dan mengurangi lama pemberian antibiotik. $^{3,10}$ Tim nosokomial dan para intensivis di ICU akan selalu mendapat tantangan dalam menghadapi infeksi oleh bakteri Gram negatif terutama yang resisten. ${ }^{3}$

\section{Epidemiologi}

Sebelum tahun 1920, infeksi yang disebabkan oleh bakteri Gram negatif sangat jarang yaitu kurang dari 1000 kasus. Sebagai contoh antara tahun 1951 dan 1958 di University of Illinois Research and Education Hospital, bakteremia Gram negatif meningkat dari 4,9 menjadi 8,1 kasus per 1000 perawatan. Hal ini juga terjadi di Boston University Hospital terjadi peningkatan dari 7,0 menjadi 13,0 kasus per 1000 perawatan antara tahun 1965 dan 1974. Lebih dari 50\% kasus bakteremia yang didapat dari rumah sakit pada anak berasal dari bakteri Gram negatif, terjadi pada usia neonatus (25\%) dan usia anak kurang dari 2 tahun $(18,5 \%)$. Diantaranya $47 \%$ merupakan infeksi nosokomial yang merupakan penyebab infeksi tersering di ICU. ${ }^{3}$

Faktor-faktor yang berpengaruh terhadap infeksi bakteri Gram negatif adalah pemberian antibiotik berhubungan dengan selective pressure pada bakteri resisten, penyakit penyerta berat dan status imunokompromais. Pada setting ICU dipertimbangkan beberapa faktor seperti kedekatan pasien dengan pasien lain yang sudah terinfeksi oleh bakteri resisten dan prosedur invasif. Semuanya merupakan faktor risiko yang signifikan meningkatkan infeksi nosokomial oleh bakteri Gram negatif. ${ }^{3}$

Klebsiella sp merupakan penyebab tersering infeksi nosokomial. Klebsiella sp penghasil ESBL seringkali bersifat multidrug resistance. Prevalensi $K$. peumoniae penghasil extended spectrum b-lactamases diantara isolat dari rumah sakit bervariasi, 45\% di Amerika Latin, 25\% di Pasifik Barat, 23\% di Eropa, 8\% di Amerika Serikat dan $5 \%$ di Kanada. ${ }^{13}$
Data dari Centers for Disease Control and Prevention (CDC), National Nosocomial Infection Surveillance (NNIS) didapatkan 17\% peningkatan jumlah tempat tidur ICU pada 117 rumah sakit antara tahun 19881995, dibandingkan dengan kapasitas total tempat tidur. Meskipun jumlah tempat tidur ICU hanya 5$15 \%$ dari seluruh tempat tidur rumah sakit, perawatan di ICU menghabiskan 10-25\% biaya perawatan rumah sakit. ${ }^{14}$

Pneumonia merupakan infeksi nosokomial terbanyak di ICU Eropa (46,9\%), diikuti infeksi saluran napas bawah lain $(17,8 \%)$, infeksi saluran kemih $(17,6 \%)$, dan bakteremia (12\%). Data dari CDC-NNIS antara tahun 1992-1997 menunjukkan infeksi didapat dari rumah sakit di ICU pada 7,8\% dari seluruh pasien yang dirawat (14.177 diantara 181.993 pasien). Infeksi saluran kemih (31\%) merupakan infeksi tersering, 95\% kasus diantaranya mendapat kateterisasi, $86 \%$ kasus pneumonia berhubungan dengan ventilator associated pneumonia (VAP). Penyakit ini merupakan $27 \%$ dari seluruh infeksi nosokomial, sedangkan bloodstream infection (BSI) mewakili 19\% (18,2\% terbukti secara laboratoris dan $0,8 \%$ sepsis secara klinis). ${ }^{14}$

Angka mortalitas bakteremia akibat infeksi nosokomial lebih besar dibandingkan infeksi di masyarakat. Sudah dibuktikan bahwa pemberian antibiotik yang adekuat akan memperpendek lama rawat dan menurunkan angka kematian. ${ }^{3,10}$ Infeksi di ICU secara signifikan berhubungan dengan kematian, yaitu $24-52 \%$ pada pasien dengan pneumonia akibat infeksi nosokomial dan 56\% pada sepsis berat. ${ }^{10}$ Angka mortalitas pasien dengan lama rawat 7 hari dengan pemberian antibiotik adekuat lebih rendah (50\%) jika dibandingkan dengan kasus yang sama dengan pemberian antibiotik tidak adekuat (54,5\%). Angka mortalitas lama rawat 30 hari, secara keseluruhan juga lebih rendah dengan terapi antibiotik adekuat $(50 \%)$ dibandingkan pemberiannya tidak adekuat $(72,7 \%)$. Lama rawat yang memanjang juga meningkatkan angka mortalitas (30\%) dibandingkan lama perawatan yang lebih pendek (20\%). ${ }^{12}$

Sudah diketahui bahwa keterlambatan pemberian antibiotik empiris dan tidak adekuat akan meningkatkan angka mortalitas. Athale $\mathrm{dkk}^{5}$ melaporkan bahwa terapi antibiotik empiris yang tidak adekuat pada lama rawat 30 hari mempunyai angka mortalitas lebih tinggi $(11,1 \%)$ dibandingkan pada lama rawat 7 hari $(3,7 \%)$. Pada terapi antibiotik empiris yang 
terlambat, tidak tampak perbedaan angka mortalitas pada lama rawat 7 hari maupun 30 hari.

\section{Mekanisme resistensi bakteri Gram negatif}

Gen pembawa resistensi bakteri berada pada plasmid, transposon, dan kromosom. Plasmid maupun transposon merupakan komponen ekstra-kromosom dan berfungsi sebagai pembawa gen resistensi pada bakteri Gram positif maupun negatif. Satu sel bakteri dapat mengandung beberapa plasmid yang sama atau lebih dari 1 jenis plasmid yang berbeda. Plasmid konjugatif di dalam suatu bakteri dapat mentransfer dirinya sendiri ke bakteri lain (spesies dapat sama/ berbeda). Transposon dalam sel bakteri dapat melompat (hop) pada kromosom atau plasmid pada bakteri yang sama atau berbeda spesies. Transposon tidak dapat replikasi sendiri, tetapi harus pada replikon seperti kromosom dan plasmid. Kromosom yang telah ditempel oleh transposon (terjadi sekuens insersi) akan berperan pada mekanisme resistensi apabila bakteri tersebut membelah diri. Adanya plasmid dan transposon memungkinkan terjadinya isolat yang multiresisten. ${ }^{15}$ Resistensi bakteri tidak hanya terjadi terhadap antibiotik yang diberikan, tetapi juga terhadap antibiotik lain disebut sebagai multidrug resistance. ${ }^{3}$
Golongan karbapenem dan sefalosporin generasi ke-empat dengan molekul yang kecil, dikenal mempunyai muatan lebih positif (muatan zwiterionik), sehingga bersifat lebih hidrofilik dan dapat melalui porin pada membran luar bakteri Gram negatif dengan mudah. Keadaan tersebut menyebabkan penetrasi antibiotik sangat baik dan tidak sempat dihidrolisis oleh enzim b-laktamase yang diproduksi oleh bakteri. ${ }^{15}$

\section{Manajemen antibiotik}

Pemilihan terapi antibiotik empiris yang adekuat dan reasonable (rasional) penting sebab akan mempengaruhi prognosis. Bagan berikut (Gambar 2) dapat membantu keputusan memilih terapi antibiotik empiris pada setting ICU. Penggunaan antibiotik yang tidak adekuat, jika antibiotik pada hasil biakan spesimen isolat yang diisolasi sensitif secara in vitro tidak diberikan secara empiris dalam waktu 24 jam setelah biakan diambil. ${ }^{16}$

Sefalosporin generasi ketiga sebaiknya tidak digunakan untuk infeksi berat bakteri penghasil ESBL, apabila pada hasil biakan sefalosporin generasi ketiga menunjukkan minimum inhibitory concentration (MIC) yang rendah terhadap mikroba ini. Pilihan antibiotik lain adalah sefalosporin

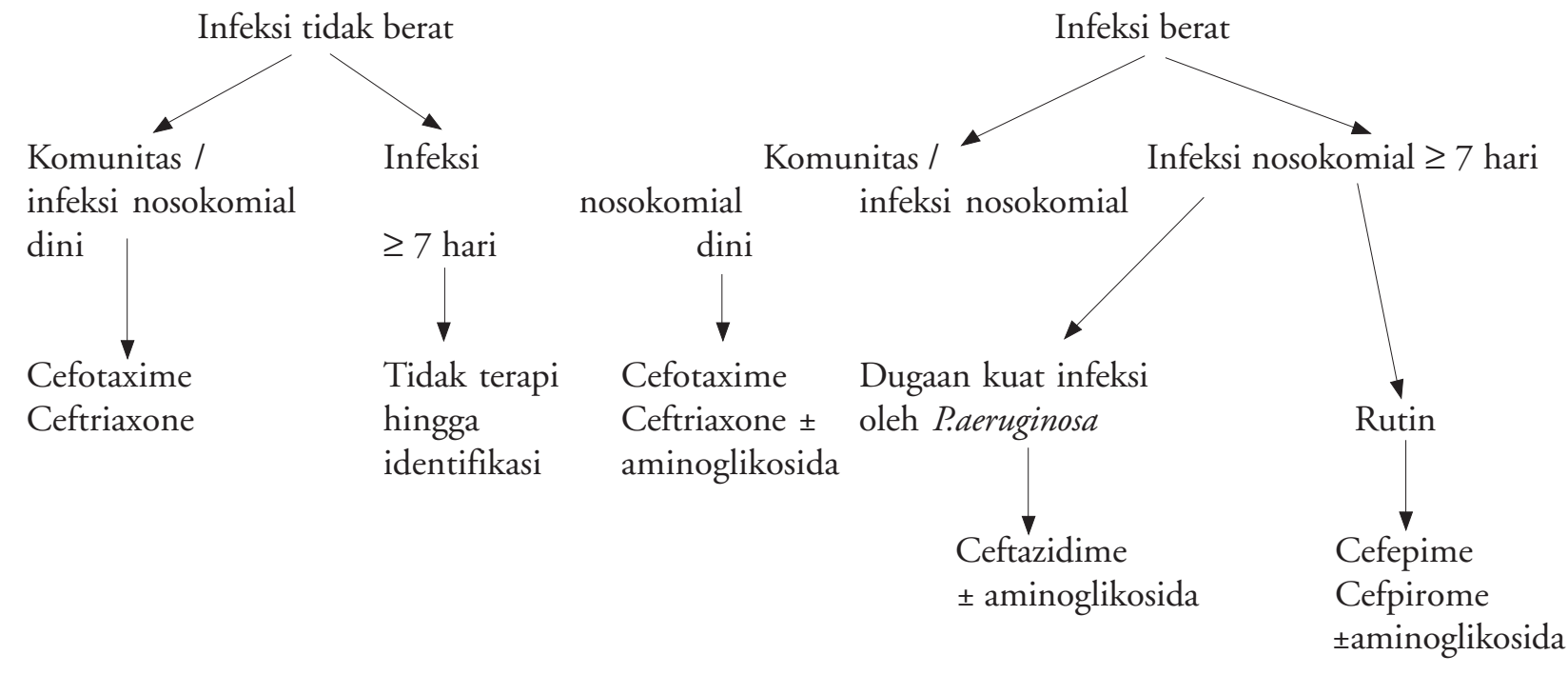

Gambar 2. Sefalosporin sebagai antibiotik empiris. ${ }^{16}$ 
generasi ke-empat (misalnya sefepim), dan kombinasi antibiotik b laktam-inhibitor b laktamase. ${ }^{13}$ Karbapenem sebaiknya disimpan, dipakai sebagai drug of choice pada infeksi yang sangat berat disebabkan bakteri penghasil ESBL. Golongan karbapenem merupakan antibiotik yang sangat poten terhadap Enterobacteriaceae sp. Meropenem sangat poten (sensitivitas 98,2-99,8\%) terhadap Enterobacteriaceae. Imipenem juga poten $(88,8 \%)$ kecuali terhadap Proteus mirabilis. ${ }^{10}$

Peningkatan resistensi bakteri yang pesat, sehingga produksi antibiotik baru tidak dapat mengejar / mendahului hal tersebut. Hal ini mengkhawatirkan, jika nantinya akan terjadi pola resistensi baru yang disebut squeezing the ballon ${ }^{6}$ atau tidak ada terapi untuk infeksi nosokomial ( $a$ doomsday scenario), yang disebut sebagai era pasca antibiotik. $^{17}$

Tabel 2 di atas merupakan contoh timbulnya pola resistensi baru (squeezing the ballon) akibat program restriksi sefalosporin dalam jangka waktu satu tahun. Pada awalnya intervensi ini tampaknya berhasil, terjadi $80 \%$ penurunan penggunaan sefalosporin, diikuti dengan penurunan prevalensi Klebsiella pneumonia yang resisten ceftazidime. Namun juga diikuti dengan peningkatan penggunaan imipenem dan resistensi Pseudomonas aeruginosa. ${ }^{18}$

Burke memberikan strategi umum penggunaan antibiotik dengan memperbaiki pembuatan resep antibiotik, yang bertujuan mengurangi munculnya resistensi terhadap antibiotik, ownership, berdasarkan bukti, pola infeksi dan resistensi setempat, perbaiki kelemahan pada sistem yang ada, partisipasi pada fasilitas yang mendukung, availabilitas antibiotik dan pertimbangan finansial. ${ }^{19}$

\section{Strategi intervensi menurunkan resistensi terhadap antibiotik}

Beberapa strategi pemakaian antibiotik untuk mengontrol resistensi ditujukan langsung dengan membatasi / memberlakukan protokol penggunaan antibiotik. Usaha ini untuk menurunkan tren peningkatan resistensi terhadap antibiotik. ${ }^{20}$ Goldmann $\mathrm{dkk}^{17}$ membuat suatu konsensus strategi untuk menghindari penyebaran bakteri resisten antibiotik di rumah sakit, yang dipegang oleh 2 tim multidisiplin. Tim pertama bertanggung jawab terhadap 5 strategi pertama yang bertujuan mengoptimalkan penggunaan antibiotik. Sedangkan tim kedua bertanggung jawab terhadap 5 strategi kedua yang bertujuan untuk deteksi, pelaporan, dan mencegah transmisi organisme resisten antibiotik. Strategi yang diputuskan oleh Society for Healthcare Epidemiology of AmericalInfectious Disease Society of America (SHEA) consensus workshop, terdiri dari 5 strategi yang bertujuan menurunkan resistensi bakteri dengan rotasi, restriksi atau kombinasi antibiotik; penggunaan antibiotik rasional dan mencegah resistensi. $^{21}$

Moss dkk melakukan rotasi antibiotik di ICU Anak tiap 3 bulan selama 18 bulan dengan mempergunakan strategi tergambar di atas. Strategi ini terbukti dapat meminimalkan munculnya resistensi terhadap antibiotik. ${ }^{22}$ Namun Toltzis dkk dalam penelitian strategi rotasi antibiotik di NICU tiap bulan selama satu tahun menyimpulkan bahwa strategi ini tidak terbukti menurunkan resistensi bakteri Gram negatif. Kegagalan ini disebabkan karena rotasi yang diterapkan terlalu cepat, paling tidak dibutuhkan waktu dua bulan untuk dapat

Tabel 2. Dampak program restriksi sefalosporin di beberapa rumah sakit di New York. ${ }^{18}$

\begin{tabular}{llll}
\hline Antibiotik & 1995 & 1996 & Perubahan (\%) \\
\hline Semua sefalosporin (g/th) & 5558 & 1106 & -80 \\
$\begin{array}{l}\text { Imipenem (g/th) } \\
\text { Ceftazidime-resisten K. pneumoniae }\end{array}$ & 197 & 474 & +140 \\
$\begin{array}{l}\text { (isolat/th) } \\
\text { Imipenem resisten K. pneumoniae }\end{array}$ & 8 & 84 & -44 \\
$\begin{array}{l}\text { (isolat/th) } \\
\text { Imipenem resisten P.aeruginosa }\end{array}$ & 67 & 0 & -100 \\
(isolat/th) & & 113 & +69 \\
\hline
\end{tabular}


memulihkan kembali sensitifitas bakteri di NICU. ${ }^{23}$ Kollef $^{20}$ dan Gruson ${ }^{24}$ melakukan penelitian prospektif dengan strategi mengubah kelas antibiotik tiap 6 bulan sebagai terapi empiris. Disimpulkan bahwa strategi ini dapat menurunkan kejadian VAP dan bakteremia nosokomial oleh bakteri Gram negatif yang resisten. Cunha ${ }^{25}$ menyatakan bahwa resistensi bakteri tidak berhubungan dengan volume, durasi ataupun kelas antibiotik, sehingga antibiotik yang tidak potensial menjadi resisten tidak perlu dilimitasi.

Keberhasilan suatu strategi antibiotik pada satu unit/ rumah sakit tergantung pada kemampuan menjawab pertanyaan: apakah perubahan yang terjadi merupakan suatu perbaikan ? Perlu cara pengukuran yang benar dan analisis data dengan menggunakan tehnik epidemiologi dan biostatistik yang tepat. Tahap penelitian dengan PDSA (plan: rencana target intervensi, do: intervensi, study: analisis data, act: ubah intervensi). Siklus diulang hingga tercapai keberhasilan pada tingkat yang diinginkan dan mempertahankannya. ${ }^{17}$

\section{Penyebaran Infeksi}

Patofisiologi infeksi nosokomial meliputi kolonisasi pasien oleh isolat yang potensial sangat patogen. Mikroorganisme berasal dari sumber endogen atau eksogen, terdiri dari strain (galur) mutan dan menjadi resisten. Adanya faktor-faktor penyakit yang mendasari cukup berat atau status imunokompromais, maka pasien dengan sakit berat sangat rentan terhadap kolonisasi yang cepat dari isolat nosokomial. ${ }^{3,10}$ Dari berbagai penelitian disimpulkan bahwa dokter dan perawat mengabaikan pentingnya mencuci tangan dengan cara yang benar sebelum dan setelah kontak dengan pasien. Sarung tangan sering tidak dipakai pada tindakan yang terindikasi, dan tangan tidak dicuci setelah melepaskan sarung tangan. Kadang-kadang dokter/perawat berpindah dari satu pasien ke pasien lain tanpa mengganti sarung tangan. ${ }^{17}$

Transmisi isolat nosokomial dari sumber eksogen dapat berasal dari tangan petugas rumah sakit yang terkontaminasi. Bakteri Gram negatif ditemukan pada $75 \%$ tangan petugas ICU dan bersifat transien. Selain itu dengan tingginya jumlah pasien di ICU, jumlah perawat yang kurang, dan terkonsentrasi pasien dengan penyakit sangat berat dan/atau kondisi imunokompromais, merupakan masalah yang sangat penting di ICU. Transmisi dari sumber endogen dapat berasal dari flora kulit, orofaring, saluran pencernaan; berkaitan dengan kemoterapi, terapi steroid ataupun antibiotik; dan penggunaan kateter urin maupun intravaskular. Flora normal di saluran pencernaan dan pernapasan dapat segera digantikan oleh isolat nosokomial. Konsentrasi isolat yang resisten mencapai jutaan per mililiter sekret bronkus/sputum atau gram feses dalam beberapa hari di ICU. ${ }^{14,17}$

Perlu diterapkan prinsip pencegahan infeksi dengan kewaspadaan universal (standar, airborne, droplet, kontak), dan kontrol penggunaan antibiotik untuk mencegah peningkatan resistensi mikroorganisme nosokomial. Strategi tersebut dapat efektif dalam jangka waktu panjang, tergantung kepatuhan seluruh petugas rumah sakit. Program pengendalian infeksi nosokomial seharusnya dapat merangkul dan mengatasi kompleksitas inter-departemen/disiplin di satu rumah sakit, dan seharusnya dijadikan prioritas dan merupakan proses yang berkelanjutan untuk perbaikan mutu suatu rumah sakit. ${ }^{14}$

\section{Isolation Precaution}

Lebih dari 50\% pasien yang dirujuk ke ICU sudah terkolonisasi mikroba dengan infeksi pada saat masuk, diantaranya sudah terkolonisasi/terinfeksi dari komunitas. Centers for Disease Control and Prevention (CDC) telah mengeluarkan protokol isolation precaution untuk mengurangi transmisi infeksi. Transmisi mikroba dapat melalui droplet airborne, droplet partikel besar atau kontak langsung. ${ }^{14}$

\section{Kewaspadaan universal (standard precaution)}

Beberapa hal yang berpengaruh mengurangi kepatuhan petugas rumah sakit adalah tidak dijadikan prioritas utama dalam penanganan pasien sehari-hari, waktu tidak cukup, fasilitas mencuci tangan tidak nyaman, kurangnya wibawa dari staf medis senior, risiko kulit kering / rusak akibat cuci tangan yang sering. Penggunaan chlorhexidine meningkatkan kepatuhan mencuci tangan, bahan ini menurunkan angka infeksi nosokomial lebih efektif dibandingkan alkohol maupun sabun. ${ }^{14}$

Transmission-Based precaution (Tabel 3)

Airborne precaution

Mencegah transmisi melalui inhalasi mikroba 
ukuran $<5 \mathrm{~mm}$, dapat bertahan di udara dalam jangka panjang dan dapat berpindah jarak jauh. Pasien ditempatkan di kamar isolasi dengan tekanan udara negatif, pergantian udara minimal $6 \mathrm{kali} / \mathrm{jam}$ dan sistem pembuangan udara yang benar. Ideal dengan disain anteroom, salah satu pintu harus tertutup bila pintu lainnya dibuka untuk mempertahankan tekanan udara.

\section{- Droplet precaution}

Mencegah transmisi mikroba berpartikel besar berukuran $>5 \mathrm{~mm}$ yang ditularkan dengan cara bersin, batuk, berbicara, atau selama tindakan invasif seperti bronkoskopi dan sedot lendir; juga mikroba didapat dari mukosa mata, hidung dan mulut. Kontak dekat jarak $<60 \mathrm{~cm}-1 \mathrm{~m}$ mempermudah transmisi ini.

\section{- Contact precaution}

Mencegah transmisi melalui kontak fisik secara langsung/tidak langsung. Pasien dirawat di kamar isolasi atau bersama dengan pasien terinfeksi dengan kuman yang sama. Petugas harus memakai sarung tangan / jubah bila kontak dengan pasien. Alat-alat seperti stetoskop / manset tekanan darah tidak boleh dipakai untuk pasien lain sebelum dilakukan disinfeksi. Pasien dengan kondisi imunokompromais ditempatkan di ruangan dengan tekanan positif. $^{14}$

\section{Program survailans (Gambar 1)}

Survailans merupakan upaya untuk menghadapi resistensi bakteri terhadap antibiotik, dengan cara memantau pola resistensi, memperbarui protokol penggunaan antibiotik, dan memperbaiki cara pencegahan transmisi infeksi. Survailans juga merupakan cara untuk mendeteksi mekanisme resistensi bakteri, kemudian melakukan intervensi dini agar tidak terjadi penyebaran gen-gen resisten dan menentukan terapi antibiotik empiris yang sesuai. ${ }^{10}$

\section{Kesimpulan}

Bakteri Gram negatif merupakan mikroorganisme patogen rumah sakit yang terbesar. Patogen ini dapat resisten terhadap antibiotik b laktam melalui berbagai mekanisme resistensi. Pneumonia merupakan infeksi terbanyak di ICU, diikuti infeksi saluran kencing dan bakteremia. Penggunaan antibiotik merupakan selective pressure terhadap timbulnya resistensi bakteri, sehingga pemilihan antibiotik empiris harus hati-hati, dan infeksi di rumah sakit dapat ditangani lebih efektif juga dengan biaya yang efektif.

Pada setting ICU, prosedur invasif yang besar, kontak yang sering antara staf rumah sakit dengan pasien, dan densitas penggunaan antibiotik yang besar merupakan faktor penting untuk berkembangnya bakteri resisten/multiresisten di ICU. Keadaan imunokompromais dan penyakit berat yang mendasari akan meningkatkan risiko terjadinya penyebaran resistensi. Salah satu solusi untuk mengurangi transmisi infeksi adalah meningkatkan compliance petugas rumah sakit misalnya dengan tehnik bedside hand-disinfection menggunakan alkohol. Perubahan sikap petugas juga tidak kalah penting, tentunya dengan pendekatan komunikasi dan alat edukasi.

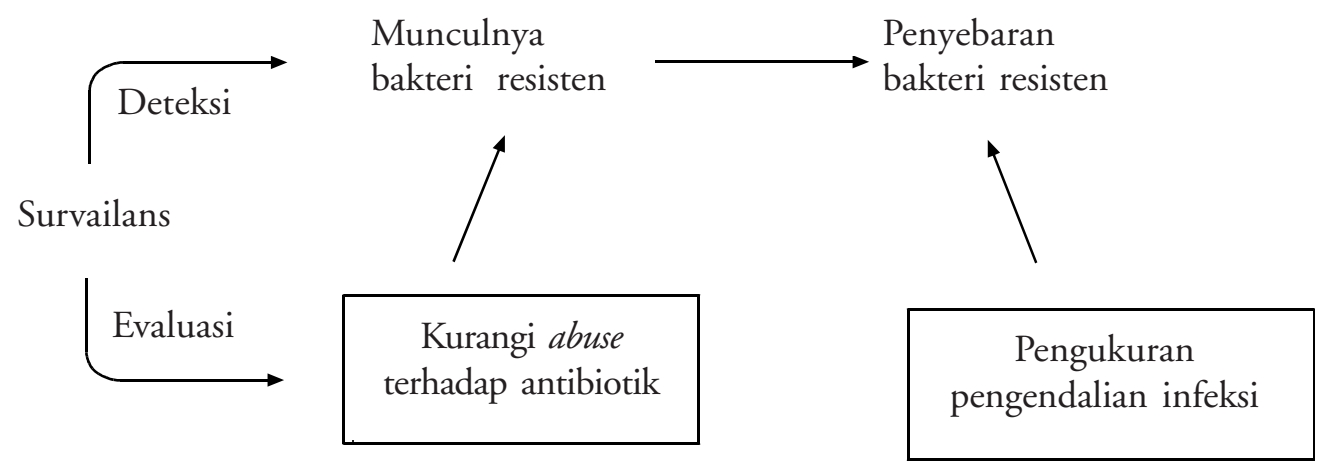

Gambar 1. Mendeteksi resistensi bakteri melalui survailans 
Tabel 3. Transmission-Based Precaution. ${ }^{14}$

Standard precaution

- Lakukan standard precaution untuk perawatan seluruh pasien

- Sebagai tambahan, lakukan precaution lain

Airborne precaution

Pada pasien tersangka/sudah diketahui mempunyai penyakit dengan transmisi droplet airborne

\section{Droplet precaution}

Pada pasien tersangka/sudah diketahui mempunyai penyakit dengan transmisi droplet partikel besar

- Meningitis, pneumonia, epiglotitis dan sepsis

- Infeksi saluran napas lain

- Infeksi virus berat

\section{Contact precaution}

Pada pasien tersangka/sudah diketahui mempunyai penyakit dengan transmisi melalui kontak langsung dengan pasien atau segala sesuatu yang terkontaminasi

- Infeksi/kolonisasi dengan bakteri yang resisten

- Infeksi enterik

- Infeksi saluran napas

- Infeksi enteroviral

- Infeksi kulit yang sangat infeksius

- Konjungtivitis viral
Campak, varisela (termasuk zoster yang luas), tuberkulosis.

- Neisseria meningitidis, H.inflenzae.

- Difteri faringeal, M.pneumoniae, pertusis, Streptococcal grup A

- Adenovirus, influenza, parotitis, parvovirus B19, rubela

- MRSA, VRE, ESBL

- P.pseudomonas dan E.cloacae multiresisten.

- C.difficile, E.coli O157:H7, shigela, hepatitis A, rotavirus.

- Respiratory syncitial virus (RSV).

- Rotavirus, parainfluenza virus.

- Difteri kulit, virus herpes simpleks, impetigo, abses terbuka, selulitis, dekubitus, pedikulosis, skabies, furunkulosis karena Staphylococcus aureus, zoster luas atau pada pasien imunokompromais.

Sumber : Healthcare Infection Control Practices Advisory Committee (HICPAC). Dikutip dari http://www.cdc.gov/acidod/hip/isolat/isolat.htm.

\section{Daftar Pustaka}

1. Al-Lawati AM, Crouch ND, Elhag KM. Antibiotic consumption and the development of resistance among Gram-negative bacilli in intensive care units in Oman. Annals of Saudi medicine 2000;20:325-7.

2. Lewis LL, Pizzo PA. Infections in the hospitalized and immunoincompetent child. Dalam: Katz SL, Gershon AA, Hotez PJ. Penyunting Krugman's Infectious diseases of children, $10^{\text {th }}$ ed. Philadelphia: Mosby,1998, p.213-35.

3. Waterer GW, Wunderink RG. Increasing threat of Gramnegative bacteria. Crit Care Med 2001;29:N75-81.
4. Georgopapadakou NH. Antibiotic resistance in enterobacteria. Dalam: Lewis K, Salyers AA, Taber HW, Wax RG. Bacterial resistance to antimicrobials, $10^{\text {th }} \mathrm{ed}$. New York: Marcel Dekker,2002, p.405-26.

5. Athale UH, Brown RC, Furman WL. Immunomodulation. Dalam: Patrick CC. Penyunting Clinical Management of Infections in Immunocompromised Infants and Children, $1^{\text {st }}$ ed. Philadelphia. Lippincott Williams \& Wilkins, 2001, p.584-615.

6. Abbas AK, Lichtman AH. Innate immunity. Dalam: Abbas AK, Lichtman AH. Penyunting Cellular and Molecular Immunology, $5^{\text {th }} \mathrm{ed}$. Philadelphia. Saunders, 
2003, p.275-97.

7. Long SS, Dowell SF. Anti-infective therapy. Dalam: Long SS, Pickering LK, Prober CG. Penyunting Principles and Practice of Pediatric Infectious Diseases, $2^{\text {nd }}$ ed. Philadelphia: Churchill Livingstone,2003, p.1422-32.

8. Toltzis P, Yamashita T, Vilt L, Blumer JL. Colonozation with antibiotic-resistant Gram-negative organisms in a pediatric intensive care unit. Crit Care Med 1997;25;538-44.

9. Niederman MS. Appropriate use of antimicrobial agents: Challenges and strategies for improvement. Crit Care Med 2003;31(2):608-16.

10. Garcia-Rodriguez JA, Jones RN. Antimicrobial resistance in Gram-negative isolates from European Intensive Care Units: data from the Meropenem Yearly Susceptibility Test Information Collection (MYSTIC) Programme. J Chemotherapy 2002;14):25-32.

11. Itzhak L, Leonard L, Moshe D, Zmira S, Hana K, Shai A. A prospective study of Gram negative bacteremia in children. Pediatr Infect Dis J 1996;15:117-22.

12. Bush K. Beta-lactamases and ESBL. Dikutip dari tayangan presentasi pada $4^{\text {th }}$ International Symposium on Antimicrobial Agents and Resistance (ISAAR) 2003, Seoul-Korea, 16-18 Juli, 2003.

13. Garau J. b-lactamase-mediated resistance in nosocomial respiratory tract infections. Dalam: Akalin HE. Penyunting Proceedings from the 3rd Net Care Meeting: Respiratory Tract Infections. Phuket-Thailand. 2001, p.37-45.

14. Eggimann P, Pittet D. Infection control in the ICU: critical care reviews. Chest 2001;120(6):2059-93.

15. Mayer KH, Opal SM, Medeiros AA. Mechanisms of antibiotic resistance. Dalam: Mandell GL, Douglas RG, Bennett JE. Penyunting Principles and Practice of Infectious Diseases, $4^{\text {th }} \mathrm{ed}$. New York: Churchill Livingstone, 1995, p.218-28.

16. Carlet J. Antibiotic management of severe infections in critically ill patients. Dalam: Dhainaut J-F,. Penyunting Thijs LG, Park G. Septic Shock, $1^{\text {st }}$ ed. London. WB
Saunders, 2000, p.445-60.

17. Goldmann DA, Weinstein RA, Wenzel RP, et al. Consensus statement: strategies to prevent and control the emergence and spread of antimicrobial-resistant microorganisms in hospitals, a challenge to hospital leadership. JAMA 1996;275:234-40.

18. Rahal JJ, Urban C, Horn D, et al. Class restriction of cephalosporin use to control total cephalosporin resistance in nosocomial Klebsiella. JAMA 1998; 280:1233-7.

19. Burke JP. Rational antibiotic use to combat the emergence of resistance. Dalam: Akalin HE. Penyunting Proceedings from the 3rd Net Care Meeting: Respiratory Tract Infections. Phuket-Thailand. 2001, p.58-66.

20. Kollef MH, Vlasnik J, Sharpless L, Pasque C, Murphy D, Fraser V. Scheduled change of antibiotic classes: a strategy to decrease the incidence of ventilator-associated pneumonia. Am J Respir Crit Care Med 1997;156:1040-8.

21. Shlaes DM, Gerdin DN, John JF Jr, et al. Society for Healthcare Epidemiology of America and Infectious Diseases Society of America Joint Committee on the Prevention of Antimicrobial Resistance: Guidelines for the prevention of antimicrobial resistance in hospitals. Clin Infect Dis 1997;25:484-99.

22. Moss WJ, Beers MC, Johnson E, et al. Pilot study of antibiotic cycling in a PICU. Crit Care Med 2002;30:1877-82.

23. Toltzis P, Dul MJ, Hoyen C, et al. The effect of antibiotic rotation on colonization with antibiotic-resistant bacilli in a neonatal intensive care unit. Pediatrics 2002;110:707-11.

24. Gruson D, Hilbert G, Vargas F, et al. Rotation and restricted use of antibiotics in a MICU: impact on the incidence of ventilator-associated pneumonia caused by antibiotic-resistant Gram-negative bacteria. Am J Respir Crit Care Med 2000;162:837-43.

25. Cunha BA. Antibiotic resistance. Medical Clinics of North America 2000;84: 1407-29. 